\title{
Pengaruh Kesadaran Merek Dan Citra Merek Terhadap Minat Beli Produk Dunkin’ Donuts Indonesia
}

\author{
Fany Sunjaya, Rezi. Erdiansyah \\ Fanysunjaya@gmail.com,Rezie@fikom.untar.ac.id \\ Fakultas Ilmu Komunikasi Universitas Tarumanagara
}

\begin{abstract}
:
The food product industry in Indonesia has increasing competition, namely donuts. Dunkin 'Donuts has a variety of donut products and with comfortable service. Market marketing at the first outlet established in Indonesia in 1985 was on Jalan Hayam Wuruk, Jakarta. Interest in buying products from Dunkin 'Donuts Indonesia regarding brand awareness and image can be explained in this study. 100 people who are consumers of Dunkin 'Donuts Indonesia in this study use quantative methods and data collection. The test method used is the coefficient of determination, correlation coefficient, T, F, Validity, Reliability, Multiple Linear Regression. This research resulted in the awareness and product brand image of Dunkin 'Donuts Indonesia together having a strong influence.
\end{abstract}

Keywords: Brand Awareness, Brand Image, Buying Interest.

\begin{abstract}
Abstrak:
Industri produk makanan di Indonesia mempunyai persaingan yang terus meningkat yaitu donat. Dunkin' Donuts mempunyai berbagai macam produk donat dan dengan pelayanan yang nyaman. Pemasaran pasar pada gerai pertama yang didirikan di Indonesia pada tahun 1985 berada di Jalan Hayam Wuruk, Jakarta. Minat Beli terhadap produk Dunkin' Donuts Indonesia mengenai Kesadaran dan Citra merek dapat dijelaskan dalam penelitian ini. 100 orang yang merupakan konsumen Dunkin' Donuts Indonesia. penelitian ini menggunakan metode kuantatif untuk pengumpulan data. Metode uji yang digunakan yaitu koefisien determinasi, koefisien korelasi, T, F, Validitas, Reliabilitas, Regresi Linier Berganda. Penelitian ini menghasilkan bahwa kesadaran dan citra merek produk Dunkin' Donuts Indonesia bersama-sama memiliki pengaruh yang erat.
\end{abstract}

Kata Kunci: Kesadaran Merek, Citra Merek, Minat Beli.

\section{Pendahuluan}

Pemasaran adalah dasar untuk membangun sebuah merek. Pemasaran Hasan 2013 yaitu sebagai cara atau metode untuk meningkatkan jumlah pembeli dan langkah naik menciptakan komunikasi yang memuaskan konsumen bagi keuntungan perusahaan.

Kesadaran merek dan Citra merek adalah dua hal yang perlu diperhitungkan dalam menjalankan pemasaran,Khususnya dalam langkah menghadapi minat beli konsumen.

Kesadaran merek menurut David A. Aaker 1997 adalah daya ingat pembeli atau calon konsumen tentang suatu produk.. Sedangkan, Brand Image menurut Rangkuti, 2004 sekumpulan-sekumpulan merek yang mulai terbentuk dan melekat dibenak konsumen. 
Minat beli konsumen yaitu adaya reaksi terhadap konsumen ketika melihat produk, dan memberikan rasa penasaran ingin mencoba dan membeli terhadap konsumen untuk memberikan rasa puas.

Berdasarkan pernyataan diatas, Peneliti ingin bertujuan untuk meneliti ketertarikan konsumen mengenai kesadaran merek dan citra merek yang baru dibuat oleh Dunkin' Donuts.

\section{Kajian Teori}

Menurut Keller dalam Soehadi 2005 terdapat empat indikator yang dapat digunakan untuk mengetahui seberapa jauh konsumen aware terdapat suatu brand, yaitu :

- Recall,

- Recognition,

- Purchase,

- Consumption

Menurut Keller 2013 dimensi-dimensi utama membentuk citra sebuah merek tertuang dalam :

- Brand Identity (identitas Merek),

- Brand Personality (Personalitas Merek),

- Brand Association (Asosiasi Merek),

- Brand Attitude and Behavior (sikap dan perilaku merek),

- Brand Benefit and Competence (Manfaat dan Keunggulan Merek).

Limartha 2018 minat beli yaitu adanya sikap dan pikiran konsumen yang mempunyai minat atau keinginan membeli, memilih suatu produk dengan berdasarkan pengalaman mengiginkan produk dakam memilih, mengkonsumsi, serta menggunakan produk.

Minat beli yaitu dapat diindentifikasi dalam beberapa indikator, yaitu:Minat transaksional, Minat Referensial, Minat Preferensial, Minat Eksploratif. (Ferdinand ) 2002 .

Kerangka pemikiran dalam penelitian ini digambarkan yaitu:

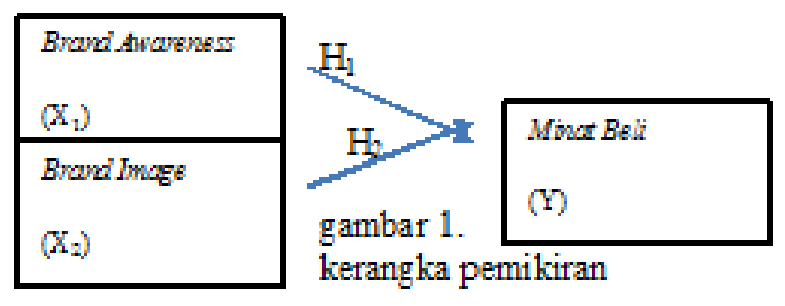

Hipotesis dari model yang dibangun di atas adalah sebagai berikut :

$\mathrm{H}_{1}$ : Brand Awareness berpengaruh positif pada Minat Beli Konsumen

$\mathrm{H}_{2}$ : Brand Image berpengaruh positif pada Minat Beli Konsumen

$\mathrm{H}_{3}$ : Brand Awareness dan Brand Image berpengaruh erat pada Minat Beli Konsumen

\section{Metodologi}

Penulis menggunakan pendekatan kuantitatif, .subjeknya adalah orang-orang yang mengetahui dan mengenali produk Dunkin' Donuts di Indonesia. 
Fany Sunjaya, Rezi. Erdiansyah: Pengaruh Kesadaran Merek Dan Citra Merek Terhadap Minat Beli Produk Dunkin' Donuts Indonesia

Teknik pemilihan sampel yang pada umumnya yaitu metode angket mengumpulkan data dan menyebarkan sehimpunan mengenai teori dan indikator untuk mendapatkan jawaban dari konsumen. Cara penelitian melakukan pengumpulan hasil data penelitian yaitu dengan cara hitungan 5 poin skala Likert, 1 untuk STS sampai 5 untuk SS dalam menyebaran kuesioner.

Variabel dependen dalam penelitian ini adalah minat beli produk Dunkin' Donuts Indonesia.Sedangkan untuk variabel independen yaitu kesadaran dan citra merek.

\section{Hasil Uji Statistik}

Dalam penelitian ini menunjukkan nilai sig. (2-tailed) sebesar 0,565 yang mengindikasikan data terdistribusi dengan normal.Selanjutnya dilakukan uji multikolinearitas yang dilihat dari nilai tolerance dan nilai VIF.Dari hasil pengolahan data diperoleh semua variabel dalam penelitian memiliki nilai tolerance $>0.10$ dan nilai VIF < 10 yang menunjukkan bahwa model regresi bebas dari masalah multikolonieritas. Uji asumsi klasik berikutnya adalah uji heteroskedastisitas yang dilihat dari nilai signifikasi > 0,05. Dari hasil pengolahan data diperoleh semua variabel dalam penelitian memiliki nilai signifikasi lebih besar dari 0,05.

Hipotesis pada penelitian ini diuji dengan menggunakan analisis regresi berganda. Berdasarkan hasil analisis regresi berganda yang dilakukan, dapat disimpulkan persamaan model regresi sebagai berikut :

Tabel 1

\begin{tabular}{|c|c|c|c|c|c|c|c|c|}
\hline \multirow{2}{*}{\multicolumn{2}{|c|}{ Model }} & \multicolumn{2}{|c|}{$\begin{array}{l}\text { Unstandardized } \\
\text { Coefficients }\end{array}$} & \multirow{2}{*}{ 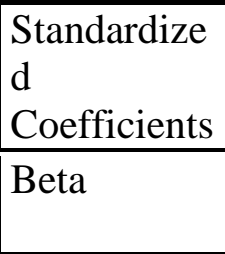 } & \multirow[t]{2}{*}{$t$} & \multirow[t]{2}{*}{ Sig. } & \multicolumn{2}{|c|}{$\begin{array}{l}\text { Collinearity } \\
\text { Statistics }\end{array}$} \\
\hline & & B & $\begin{array}{l}\text { Std. } \\
\text { Error }\end{array}$ & & & & \begin{tabular}{|l|} 
Toleranc \\
$\mathrm{e}$
\end{tabular} & VIF \\
\hline & (Constant & 1.134 & 1.403 & & .784 & .435 & & \\
\hline 1 & BA & 233 & ,089 & ,217 & $\begin{array}{l}2,62 \\
9\end{array}$ & ,010 & ,585 & $\begin{array}{l}1,70 \\
9\end{array}$ \\
\hline & BI & ,482 & ,063 & ,626 & $\begin{array}{l}7,59 \\
3\end{array}$ & ,000 & ,585 & $\begin{array}{l}1,70 \\
9\end{array}$ \\
\hline
\end{tabular}

a. Dependent Variable: MB

$\mathrm{Y}=1,134+0,233 \mathrm{X} 1+0,482 \mathrm{X} 2$

Dari persamaaan regresi di atas, koefisien konstan menunjukkan angka 1,134.

Hal tersebut menunjukkan apabila variabel independen tersebut sama dengan 0 , maka variabel Minat Beli bernilai 1,134.

Variabel brand awareness memiliki nilai koefisien regresi sebesar 0,233. Hal ini menunjukkan pengaruh positif brand awarenessterhadap minat beli produk

Dunkin' Donuts Indonesia. Variabel brand awarenessakanmengalami kenaikan sebesar 0,233 satuan apabila variabel ke Minat Beli mengalami kenaikan 1 satuan.

Variabel citra merek memiliki nilai koefisien regresi sebesar 0,482. Dengan adanya penelitian ini pengaruh positif brand image terhadap minat beli produk 
Dunkin' Donuts Indonesia. Variabel brand imageakanmengalami kenaikan sebesar 0,482 satuan apabila variabel Minat Beli mengalami kenaikan 1 satuan.

Uji F menunjukkan apakah semua variabel independen yang dimasukkan dalam model mempunyai pengaruh secara bersama-sama terhadap variabel dependen. Jika nilai signifikasi lebih kecil dari 0,05 , maka dinyatakan $\mathrm{H}_{0}$ ditolak dan $\mathrm{H}_{\mathrm{a}}$ diterima. Hasil uji F dapat dilihat pada tabel 2.

Tabel 2

\begin{tabular}{|rl|r|r|r|r|r|}
\hline \multicolumn{1}{|l|}{ Model } & Sum of Squares & \multicolumn{1}{c|}{ df } & Mean Square & \multicolumn{1}{c|}{ F } & \multicolumn{1}{c|}{ Sig. } \\
\hline \multirow{2}{*}{1} & Regression & 960,582 & 2 & 480,291 & $\mathbf{7 7 , 1 1 1}$ & $\mathbf{0 0 0}^{\mathbf{b}}$ \\
& Residual & 604,168 & 97 & 6,229 & & \\
& Total & 1564,750 & 99 & & & \\
\hline
\end{tabular}

a. Dependent Variable: MB

b. Predictors: (Constant), BI, BA

\section{Diskusi}

Diskusi dari hasil pengujian statistik dengan uji koefisien menunjukkan bahwa adanya brand awareness, brand image produk Dunkin' Donuts Indonesia secara bersama-sama memiliki hubungan yang baik.

Hasil pengujian statistik dengan uji $\mathrm{F}$ kesadaran dan citra merek produk Dunkin' Donuts Indonesia secara bersama-sama berpengaruh.

Brand Awareness memiliki hubungan yang erat terhadap Minat Beli Produk Dunkin' Donuts Indonesia dan mempunyai arah hubungan positif, yang berarti variabel ini mempengaruhi Minat Beli Produk Dunkin' Donuts Indonesia, dengan variabel Brand Awareness mengalami kenaikan maka variabel kepatuhan Minat Beli Produk Dunkin' Donuts Indonesia juga akan mengalami kenaikan.

Brand Image berpengaruh signifikan terhadap Minat Beli Produk Dunkin' Donuts Indonesia dan mempunyai arah hubungan positif, yang berarti variabel ini mempengaruhi Minat Beli Produk Dunkin' Donuts Indonesia, dengan variabel Brand Image mengalami kenaikan maka variabel kepatuhan Minat Beli Produk Dunkin' Donuts Indonesia juga akan mengalami kenaikan.

Kesadaran merek dan Citra merek berpengaruh positif terhadap Produk Dunkin' Donuts Indonesia secara bersama-sama. Dari hasil penelitian pada studi responden yang merupakan konsumen Dunkin' Donuts Indonesia, adanya pengaruh yang cukup positif terhadap variabel minat beli Dunkin' Donuts Indonesia yang menandakan semakin baik citra merek yang telah dibangun, maka akan berpengaruh tinggi dalam minat beli. Terakhir, begitu juga dengan kesadaran merek yang membuat Dunkin' Donuts merubah beberapa konsep untuk lebih meningkatkan minat beli Dunkin' Donuts Indonesia berpengaruh positif. 
Fany Sunjaya, Rezi. Erdiansyah: Pengaruh Kesadaran Merek Dan Citra Merek Terhadap Minat Beli Produk Dunkin' Donuts Indonesia

\section{Ucapan Terima Kasih}

Penulis pada kesempatan ini sangat mengucap syukur dan berterima kasih banyak kepada Tuhan Yang Maha Esa, dan juga kepada Bapak Dr. Rezi Erdiansyah, M.Si, yaitu selaku pembimbing saya yang telah baik dan dengan sabar dalam menuntun saya untuk menyelesaikan skripsi dan juga jurnal, dan kepada keluarga, dosen-dosen, responden penelitia, dan pihak- pihak lain yang ikut dalam proses penyelesaian penelitian ini.

\section{Daftar Pustaka}

Aaker, David A. (1991). Managing Brand Equity: Capitalizing on The Value of Brand Name. New York. The Free Press. Mc. Millan Inc.

Aritonang, R. Lerbin, R. 2007. Teori dan Praktik Riset Pemasaran. Bogor: Ghalia Indonesia

Bagong, Suyanto, dan Sutinah.2008.Metode Penelitian Sosial:Berbagai Alternatif

Basu, Swastha, \& Irawan, 2001, Manajemen Pemasaran Modern, Liberty.Yogyakarta.

Bungin, Burhan. 2005. Metode Penelitian Kuantitatif. Jakarta: Prenadamedia

Durianto, Darmadi. (2001). Strategi Menaklukan Pasar Melalui Riset Ekuitas Dan Perilaku.Jakarta : PT Gramedia Pustaka Utama

Fandy Tjiptono. 2005. Brand Management and strategy. (Edisi Pertama).Andi : Yogyakarta

Ferdinand, Augusty. 2002. Structural Equation Modelling dalam Penelitian Manajemen. Semarang:FE UNDIP.

Ghozali, Imam. 2011. "Aplikasi Analisis Multivariate Dengan Program SPSS". Semarang: Badan Penerbit Universitas Diponegoro.

Ghozali, Imam. (2007). Aplikasi Analisis Multivariate dengan Program SPSS). Badan Penerbit Universitas Diponegoro, Semarang

Husein, Umar. 2008. Metode Penelitian Untuk Skripsi dan Tesis Bisnis. Jakarta. PT Rajagrafindo Persada

J. Setiadi, Nugroho, SE., MM., 2003, "Perilaku Konsumen Konsep dan Implikasi untuk Strategi dan Penelitian Pemasaran". Jakarta: Kencana

Kahle, Lynn R \& Chung-Hyon Kim. 2006. Creating Images and The Psychology of Marketing Communication. Routledge

Keller, K. L. (2003). Strategic Brand Management: Building, Measuring, and Managing Brand Equity Second Edition. New Jersey: Pearson Education, Inc.

Kriyantono, Rachmat. 2006. Teknik Praktis Riset Komunikasi.Jakarta : Kencana Prenada Media Group.

Kriyantono, Rachmat. 2009. Teknik Praktis Riset Komunikasi. Malang: Prenada Media Group

Kotler dan Keller. 2009. Manajemen Pemasaran. Jilid I. Edisi ke 13. Jakarta: Erlangga

Kotler dan Keller. 2005, Manajemen Pemasaran, Jilid I dan II, PT. Indeks Jakarta

Kotler dan Keller. 2012, Manajemen Pemasaran, Edisi 12,Jakarta : Erlangga

Martono, Nanang. 2010. Metode Penelitian Kuantitatif. Jakarta: PT Raya Grafindo Persada 
Moleong, Lexy.(2002). Metodologi Penelitian Kualitatif. Bandung: PT. remaja Rosdakarya.

Rangkuti, Freddy (2002), Measuring Customer Satisfaction, Penerbit PT Gramedia Pustaka Utama, Jakarta

Limartha, Erdiansyah, 2018. Pengaruh Brand Equity dan Product Knowledge Terhadap Minat Beli Konsumen Komunitas Hello Beauty Jakarta pada Produk Wardah. Jurnal Untar Prologia,5.

Sugiyono. 2006.Metode Penelitian Kuantitatif, Kualitatif dan $R \quad \&$ D.Bandung:Alfabeta.

Sugiyono. 2010. Metode Penelitian Pendidikan Pendekatan Kuantitatif, kualitatif, dan $R \& D$. Bandung: Alfabeta

Sugiyono. (2017). Metode Penelitian Kuantitatif, Kualitatif, dan R\&D.Bandung : Alfabeta, CV.

Umar, Husein, 2002, Riset Pemasaran dan Perilaku Konsumen, Penerbit PT. Gramedia Pustaka Utama, Jakarta.

Vardiansyah, Dani. 2004. Pengantar Ilmu Komunikasi :Pendekatan Taksonomi Konseptual. Ghalia Indonesia, Jakarta. 